\title{
Effect of carbon and nitrogen sources on polygalacturonase production by Trichoderma viride (BITRS-1001) isolated from tar sand in Ondo State, Nigeria
}

\author{
Arotupin, Daniel Juwon and Ogunmolu, Funso Emmanuel \\ Department of Microbiology, Federal University of Technology Akure, Ondo state, Nigeria. \\ E-mail:blessedfunso@yahoo.co.uk, blessedfunso@gmail.com
}

Received 7 January 2011; received in revised form 14 June 2011; accepted 1 July 2011

\begin{abstract}
The effects of the various carbon and nitrogen substrates on the growth and polygalacturonase activity of Trichoderma viride (BITRS-1001) isolated from the tar sand deposit in Gbelejuloda-Irele Ondo State, Nigeria were investigated in submerged cultivation at $30{ }^{\circ} \mathrm{C} \pm 2{ }^{\circ} \mathrm{C}$. The commercial carbon and nitrogen substrates included sucrose, fructose, starch, maltose, lactose and peptone, sodium nitrate, urea and casein respectively. All the carbon substrates used supported the growth of $T$. viride ( 0.566 to $0.156 \mathrm{~g} / 50 \mathrm{~mL}$ of culture medium) with starch supporting the highest biomass yield and sucrose the least biomass yield. Maximum polygalacturonase activity of $3033 \mathrm{U} / \mathrm{mL}$ was recorded in maltose medium. Maximum biomass yield on the nitrogen sources was observed in the organic nitrogen namely peptone and casein with values not significantly different from each other at $p \leq 0.05$. In the determination of the crude enzyme activity on the nitrogen sources, maximum polygalacturonase activity of $12,400 \mathrm{U} / \mathrm{mL}$ was recorded in peptone medium. Hence, a careful manipulation of these nutrient substrates could help to optimise the production of this enzyme on a large scale.
\end{abstract}

Keywords: Growth, substrates, polygalacturonase, tar sand, cultivation, biomass

\section{INTRODUCTION}

Microbes are rich sources of enzymes (Akpan, 2004). In recent years, the potentials of using microorganisms as biotechnological sources of industrially relevant enzymes has stimulated interest in the exploration of extracellular enzymatic activity in several microorganisms (Akpan, 2004; Jayani et al., 2005; Varalakshmi et al., 2007). Although enzymes have traditionally been extracted from plants and animals, microbial enzymes has formed the basis of commercial enzyme production. This is because, of the increasing availability of these microorganisms and their ease of improvement by the manipulation of their genes and environment; great diversity of enzymes which cannot be obtained from plant and animal sources; and high production capability at low cost among others (Onyeocha and Ogbonna, 1983; Alves et al., 2002; Akinyosoye et al., 2003; Vieira et al., 2006). Among the various enzymes commercialized, many are the products of fermentation of filamentous fungi (Piccoli-Valle et al., 2001).

Pectinases (pectinolytic enzymes) is a general term for enzymes commonly referred to in brewing as pectic enzymes. Pectinases are of great significance with tremendous potential to offer to industry. They are one of the upcoming enzymes of the commercial sector, especially the juice and food industry and in the paper and pulp industry (Beg et al., 2001; Kashyap et al., 2001; Jacob and Prema, 2006). Pectinases include depolymerizing and demethoxylating enzymes.
Depolymerizing enzymes are polygalacturonase (EC 3.2.1.15), which cleaves the $\alpha-1,4$ glycosidic bonds between two galacturonic acid residues, and pectin-lyase (EC 4.2.2.10), which catalyses a $\beta$-elimination reaction between two methylated residues. De-esterifying enzymes include pectin-esterase (EC 3.1.1.11), which catalyses the demethoxylation of methylated pectin, producing methanol and pectin (Soares et al., 1999). The synthesis of pectinases by microorganisms has been reported to be highly influenced by factors such as carbon sources, temperature, $\mathrm{pH}$ and operating parameter such as incubation time in submerged culture (Jacob and Prema, 2006; Palaniyappan et al., 2009).

Soils are the particulate materials of the outer crusts of the earth surface formed through the continuous weathering of the underlying parent rock (Arotupin and Akinyosoye, 2008). It overlies the earth's bedrock and contains little organic matter (Robert et al., 2006). The soil is such a diverse environment that the microbial populations differ tremendously from soil to soil; even within the same soil over the course of a season. The vast differences in the composition of soils, physical characteristics and the agricultural practices by which they are cultivated, result in corresponding large differences in the microbial population both in the numbers and kinds (Pelczar et al., 1993; Zeki et al., 2010). Tar sand for example is composed of sand, bitumen and clays that are rich in minerals and water (Oboh et al., 2006). It is present in vast amount in South Western Nigeria totaling about the largest deposit in the World (Adebiyi et al., 2005). It has 
an estimated reserve of about forty billion barrels of bituminous sand in place (Oguntimehin and Ipinmoroti, 2007). Several types of microorganisms have been found in association with the Nigerian tar sand deposit with their oil degrading ability reported by Oboh et al. (2006) and Adebayo et al. (2009). However, little or no work has been done in exploring these microorganisms as potential sources of industrially important enzymes.

The present study was therefore aimed at evaluating the effects of different commercial carbon and nitrogen substrates on the polygalacturonase activity of the Trichoderma viride (BITRS-1001) previously isolated from tar sand deposit in Ondo State Nigeria.

\section{MATERIALS AND METHODS}

\section{Source of microorganism}

The fungus strain used in the present study was isolated from tar sand samples collected from Gbelejuloda-Irele, Nigeria and identified as Trichoderma viride (BITRS-1001) in the research laboratory of the Department of Microbiology, Federal University of Technology Akure, Nigeria. The culture was maintained on Sabouraud dextrose agar slants incorporated with $0.1 \%$ tetracycline kept at $4^{\circ} \mathrm{C}$ and subcultured at regular intervals.

\section{Screening of the fungal isolates for PG production}

The fungus was screened for PGase using the method described by Onyeocha and Ogbonna (1983) and Vieira et al. (2006). The composition of the medium is as presented: mineral salt solution $(500 \mathrm{~mL})$, peptone $(1 \mathrm{~g})$, agar $(15 \mathrm{~g})$, pectin $(5 \mathrm{~g})$ and distilled water $(500 \mathrm{~mL})$. The medium was brought to $\mathrm{pH} 5$ with $0.1 \mathrm{M} \mathrm{HCl}$ and $0.1 \mathrm{M}$ $\mathrm{NaOH}$. The plates were inoculated and incubated at $30^{\circ} \mathrm{C}$ for $96 \mathrm{~h}$. After this, $5.0 \mathrm{~mL}$ of $\mathrm{HCl}(2 \mathrm{~mol} / \mathrm{L})$ was added to the plates and the presence of clear halo around the colonies was indicative of the degradation of pectin.

\section{Cultural conditions and production of $P G$ in submerged cultivation ( $\mathrm{SmC}$ )}

The production of the PG enzymes was carried out in 250 $\mathrm{mL}$ conical flask each containing $50 \mathrm{~mL}$ basal medium using modified Arotupin (2007). The composition of the basal medium include peptone $1 \mathrm{~g} ; \mathrm{KH}_{2} \mathrm{PO}_{4} 1.05 \mathrm{~g} ; \mathrm{NaNO}_{3}$ $4 \mathrm{~g} ; \mathrm{MgSO}_{4} \cdot 7 \mathrm{H}_{2} \mathrm{O} 0.1 \mathrm{~g} ; \mathrm{Na}_{2} \mathrm{HPO}_{4} 2 \mathrm{~g}$; sucrose $20 \mathrm{~g}$ and distilled water $1000 \mathrm{~mL}$. The medium was adjusted to $\mathrm{pH}$ 6.00. A sterile cork borer of $15 \mathrm{~mm}$ diameter was used to cut a disc from the advancing edge of a 5-day old funga isolate. The disc was used to inoculate the medium. Fermentation was carried out at $30{ }^{\circ} \mathrm{C}$ in a Gallenkamp BKS-350-0010 orbital incubator shaker operating at 80 rpm for 10 days. The following were monitored daily: biomass/growth (estimated as the dry weight of mycelium per $50 \mathrm{~mL}$ ), $\mathrm{pH}$, and polygalacturonase (PG) activity.

To investigate the influence of carbon and nitrogen sources on the enzyme activities of $T$. viride (BITRS-1001) in submerged cultivation, sucrose was replaced with fructose, maltose, lactose and starch; while the mixture of sodium nitrate and peptone was substituted with peptone, casein, sodium nitrate and urea.

\section{Biomass/growth determination of fungal isolates}

The method of Narasimha et al. (2006) was employed. The biomass or mycelia growth produced in the liquid culture medium was determined by dry weight measurement. Whatman No.1 filter paper was dried to constant weight, and the weight noted. The content of the flask was filtered through the filter paper to separate the mycelia mat and the culture filtrate. The biomass of the culture (residue) was dried until a constant weight was obtained. The growth yield per $50 \mathrm{~mL}$ of broth was determined using a Mettler balance (PM 400). The biomass/growth was calculated thus:

Biomass $(\mathrm{mg} / 50 \mathrm{~mL})=$ Weight of culture + filter paper initial weight of filter paper

\section{$\mathrm{pH}$ determination of the culture filtrate}

The $\mathrm{pH}$ value of the culture filtrates was obtained by using an electronic $\mathrm{pH}$ meter, Hanna pH 209 that had been previously standardized with appropriate buffer solutions of $\mathrm{pH} 4,7$ and 9 . The electrode of the standardized $\mathrm{pH}$ meter was inserted into the crude filtrate of the isolate. The values were immediately read on the meter record and values recorded. This was done throughout the period of the experimental setup (Arotupin, 2007).

\section{Assay for polygalacturonase activity of the culture filtrate}

Polygalacturonase (PG) activity of the respective culture filtrate was assayed by measuring the amount of reducing sugar released in the reaction mixture. The reaction mixture consisted of $1 \mathrm{~mL}$ of $1.2 \% \mathrm{w} / \mathrm{v}$ pectin in $1 \mathrm{~mL}$ of $0.1 \mathrm{M}$ citrate-phosphate buffer of $\mathrm{pH} 5.0$ and $1 \mathrm{~mL}$ of crude filtrate (crude enzyme solution). Control experiment tubes contained the same amount of substrate and $1 \mathrm{~mL}$ of the crude filtrate (crude enzyme solution) boiled for 15-20 min. Both the experimental and control tubes were incubated at $35{ }^{\circ} \mathrm{C}$ for $3 \mathrm{~h}$. The reducing sugar released into the reaction mixture was determined by the method of 3,5 dintrosalicyclic acid (DNSA) reagent (Arotupin, 2007). One unit of polygalacturonase activity was defined as the amount of enzyme in $1 \mathrm{~mL}$ that would liberate reducing sugar equivalent to $1 \mathrm{\mu g}$ galacturonic acid per minute under the specific conditions of reaction.

Three mililitre of DNSA reagent $(\mathrm{NaOH} 10 \mathrm{~g}$; Na/Ktartarate $20 \mathrm{~g}$; 3, 5-dinitrosalicyclic acid $10 \mathrm{~g}$ and distilled water $1000 \mathrm{~mL}$ ) was added to $1 \mathrm{~mL}$ of each of the test sample in the test tubes. The mixture was properly mixed and heated in boiling water for $15 \mathrm{~min}$ and cooled in tap water. The absorbance was taken at $540 \mathrm{~nm}$ with a UNICO 1100RS spectrophotometer. Serial dilutions of galacturonic acid were treated in the same manner and the absorbance reading taken and used to plot a standard curve for polygalacturonase (PG). The unknown amount 
of reducing sugar in each test sample was extrapolated from the standard curve.

\section{Statistics}

The numerical data obtained during the investigations were subjected to Analysis of Variance and inferences at 95\% confidence limits using the SPSS 15.0 software package. Duncan's New Multiple Range Test was used to separate means.

\section{RESULTS}

The mycelia dry weight and polygalacturonase activity of the culture filtrates of $T$. viride (BITRS-1001) were determined with various commercial carbon sources viz starch, lactose, fructose, maltose and sucrose. All the commercial carbon sources supported the good growth of the fungal isolates as well as the production of the enzymes. $T$. viride had the highest biomass yield of 0.566 $\mathrm{g} / 50 \mathrm{~mL}$ of culture in starch, followed by $0.460 \mathrm{~g} / 50 \mathrm{~mL}$ in fructose, $0.317 \mathrm{~g} / 50 \mathrm{~mL}$ in maltose and $0.298 \mathrm{~g} / 50 \mathrm{~mL}$ in lactose, while sucrose had the least biomass yield of $0.1560 \mathrm{~g} / 50 \mathrm{~mL}$ culture medium (Figure 1). The $\mathrm{pH}$ values of the culture filtrate ranged from 3.60-6.39 for sucrose, 5.12-6.87 for fructose, 5.35-6.73 for starch, 5.20-6.45 for maltose and 5.24-6.40 for lactose (Figure 2). Lactose had the highest polygalacturonase activity of $3500 \mathrm{U} / \mathrm{mL}$ on the 7 th day, maltose $(3033 \mathrm{U} / \mathrm{mL}$ on the 3rd day), fructose (1133.33 U/mL on the 1 st day), starch $(633.33 \mathrm{U} / \mathrm{mL}$ on the 5th day) and sucrose with activity $433.33 \mathrm{U} / \mathrm{mL}$ on the 1st day (Figure 3).

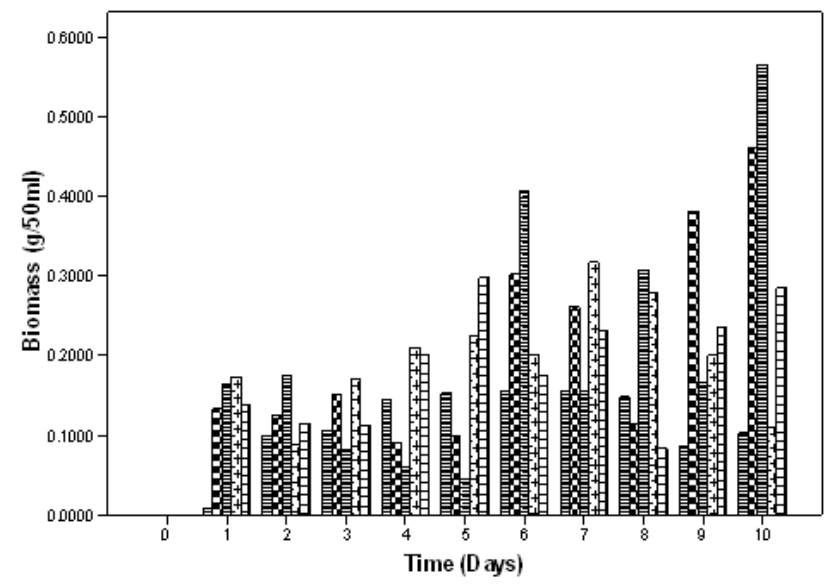

Carbon Source

$$
\begin{aligned}
& \text { 曷 Sucrose } \\
& \text { Fructose } \\
& \text { Starch } \\
& \text { 由utaltose } \\
& \text { 由 Lactose }
\end{aligned}
$$

Figure 1: Effect of different carbon sources on the growth of Trichoderma viride in submerged culture.

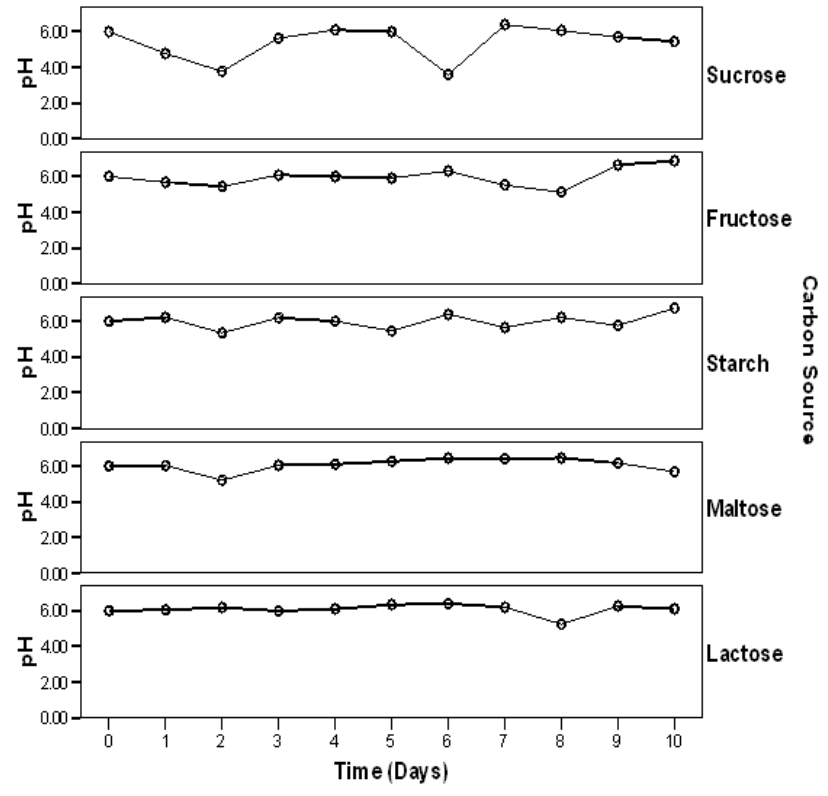

Figure 2: $\mathrm{pH}$ variations in the culture media during fermentation in submerged culture.

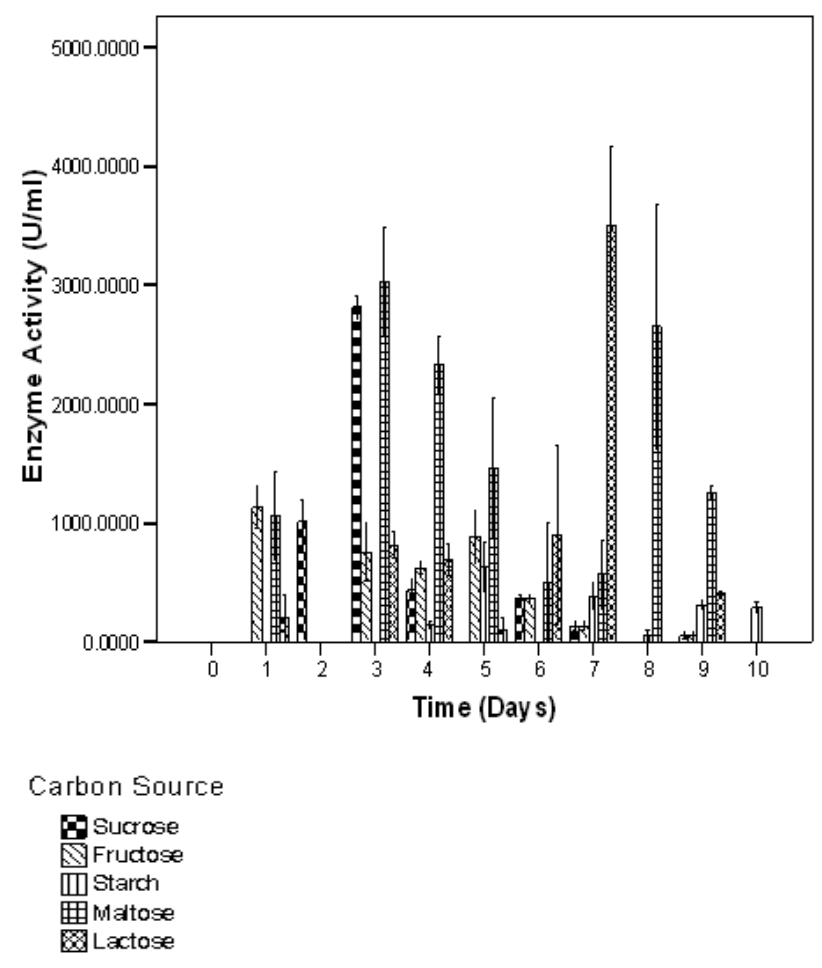

Figure 3: Effect of different carbon sources on polygalacturonase activity of Trichoderma viride in submerged culture. 
The effect of different nitrogen sources on the growth and enzyme production of $T$. viride (BITRS-1001) using maltose as the sole carbon source is shown in Figures 45 . The various nitrogen sources stimulated the growth of the fungus and the production of $P G$ in varying degrees. $T$. viride grew best in media containing casein and peptone as nitrogen sources with mycelia growth of 0.401 $\mathrm{g} / 50 \mathrm{~mL}$ on day 5 and $0.400 \mathrm{~g} / 50 \mathrm{~mL}$ on day 10 respectively. Peptone + sodium nitrate had the maximum biomass growth of $0.317 \mathrm{~g} / 50 \mathrm{~mL}$ on day 7 , sodium nitrate $(0.310 \mathrm{~g} / 50 \mathrm{~mL}$ on day 8$)$ and urea with a value of 0.186 $\mathrm{g} / 50 \mathrm{~mL}$ on day 6 of the culture medium (Figure 4). For the polygalacturonase activity of $T$. viride (BITRS-1001) in the various nitrogen substrates, peptone had the highest polygalacturonase activity of $12,400 \mathrm{U} / \mathrm{mL}$ on day 1 , casein (6933.33 $\mathrm{U} / \mathrm{mL}$ on day 3$)$, peptone + sodium nitrate (3033.33 $\mathrm{U} / \mathrm{mL}$ on day 3 ) and urea (2450 $\mathrm{U} / \mathrm{mL}$ on day 3 ) (Figure 5).

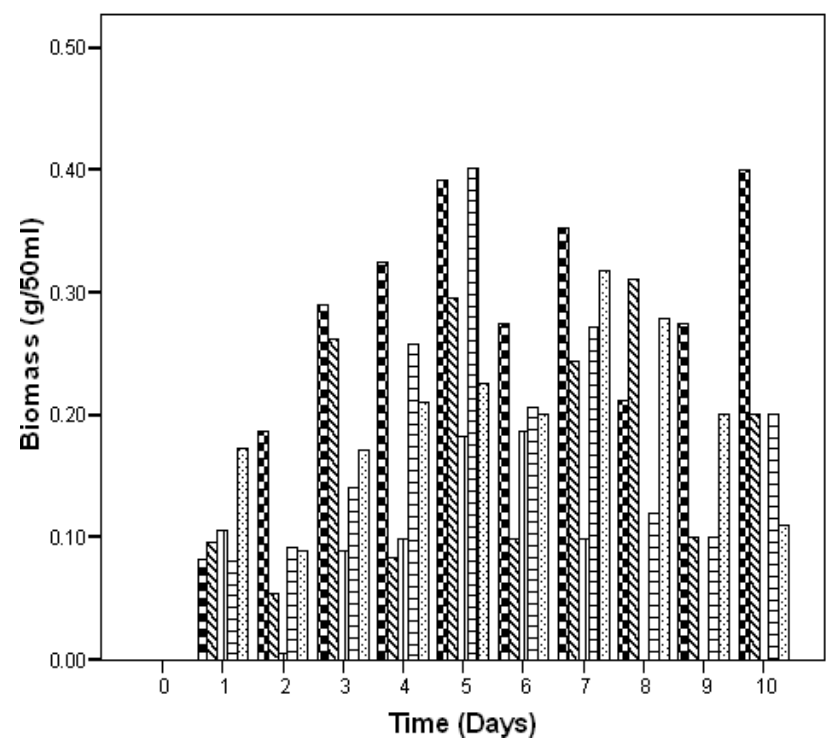

Nitrogen Sources

$$
\begin{aligned}
& \mathbf{8} \text { Peptone } \\
& \mathbb{N} \text { Sodium Nitrate } \\
& \text { 岗 Urea } \\
& \text { 思 Casein } \\
& \text { Peptone+sodium Nitrate }
\end{aligned}
$$

Figure 4: Effect of different nitrogen sources on the biomass growth of Trichoderma viride in submerged culture.

\section{DISCUSSION}

In the preliminary screening of the fungus for the production of PGase, T. viride (BITRS-1001) rapidly utilized pectin with a halo diameter of $6.43 \mathrm{~cm}$ in $96 \mathrm{~h}$. This is an indication of polygalacturonase production by the fungus. Several microorganisms have been reported to being endowed with vast potentials to produce arrays of

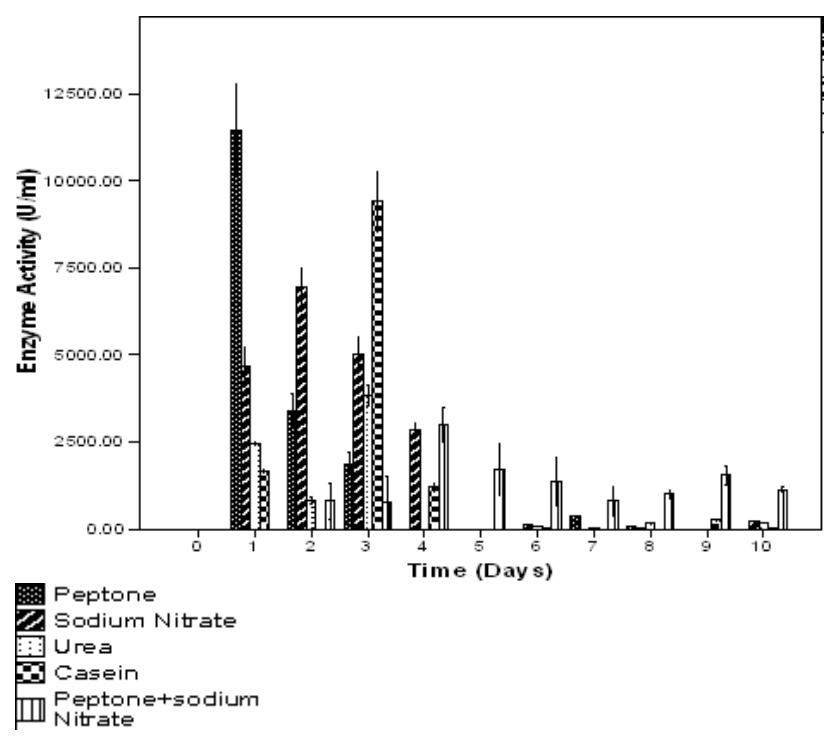

Figure 5: Effect of different nitrogen sources on polygalacturonase activity of Trichoderma viride in submerged culture.

enzymes (Jayani et al., 2005; Varalakshmi et al., 2007). The result of this study also revealed that all the commercial carbon sources supported the good growth of $T$.viride (BITRS-1001) as well as the production of the enzyme PG in submerged cultivation. This is an indication that the fungus had the ability to utilize the various commercial carbon sources as substrates for growth. Moore-Landecker (1996) had earlier stated that fungi being heterotrophs obtain their required nutrients from the organic matter in the environment and thus are able to utilize a wide range of carbon substrates as source of energy. This ability has been attributed to the competitive saprophytic ability of fungi expressed by fast mycelia growth, spores production, presence of efficient and extensive systems of powerful enzymes (Silva et al., 2005; Khalid et al., 2006).

Of the carbon sources tested, the polysaccharidestarch supported the maximum biomass yield of $T$. viride, followed by fructose (monosaccharide). The least biomass yield was observed in the disaccharides in the following order: maltose, lactose and sucrose. Akinyosoye et al. (2003) had earlier reported that starch supported the maximum biomass yield of Geotrichum candidum and Phoma sorghina better than disaccharides (maltose and lactose), monosaccharides (glucose, fructose and galactose). However, Arotupin (2007) on the contrary reported that starch supported the least biomass yield of Aspergillus spp. grown in submerged cultivation. This observed maximum biomass yield in starch may possibly be due to the fact that starch is the most abundant organic carbon source in the environment serving as the major reserve carbohydrate of all higher plants, cum the fact that it is extensively degraded by $\alpha$-amylase, which is readily produced by $T$. viride (Aiyer, 2005). The abundant growth 
of fungi in starch also, may be attributed to the ability of the fungus to hydrolyze starch to monomeric units of glucose which is easily transported through the plasmalemma and phosphorylated to yield energy.

Results from this investigation on the effects of the different commercial carbon substrate tested on PG production revealed that the fungus is capable of utilizing these non-natural inducers for the production of polygalacturonase in submerged cultivation. Although Favela-Torres et al. (2006) and Akhilesh et al. (2010) had earlier on reported pectin as a natural inducer of polygalacturonase in submerged cultivation. This ability expressed by $T$. viride (BITRS-1001) indicates that polygalacturonase production is not only inducible but constitutive. Of the carbon substrates tested, the ability of maltose to support maximum $P G$ activity within the shortest incubation time is desirable in comparison to the other sugar in industrial processes. Thus, maltose was chosen as the carbon substrate of choice for the remainder of the work in testing for the effect of different nitrogen substrate on PG production by $T$. viride (BITRS1001 ) in submerged cultivation.

The organic nitrogen substrates tested peptone and casein supported better biomass yield and PG activity of the fungus as compared to the inorganic nitrogen substrates tested. This is in consonance with Arotupin (2007) who reported that organic nitrogen sources tend to support the good growth of fungi more than inorganic nitrogen sources. Vahidi et al. (2004) equally reported that good growth and antifungal activities were observed when complex nitrogen sources (yeast extract and peptone) were used compared to inorganic nitrogen source $\left(\mathrm{NH}_{4} \mathrm{C}\right.$ and $\mathrm{NaNO}_{3}$ ). This implication may be that the organic nitrogen sources serves as good growth stimulators. During growth, the fungi probably hydrolyze the organic nitrogen releasing their mineral component and other growth factors in them into constituents that can be easily incorporated into the cellular metabolism. The precedence of organic nitrogen sources over inorganic substrates in PG production was reported by Akhilesh et al. (2010) who hinted that the best polygalacturonase production was obtained with Mucor circinelloides ITCC 6025 when casein hydrolysate and yeast extract were used together.

In this experiment, visible variations were observed in the $\mathrm{pH}$ of the culture medium as a result of the fungus growth. This is in conformity with Griffin (1994) and Moore-Landecker (1996) who reported that, fungi invariably alter the $\mathrm{pH}$ of the medium in which they grow due to uptake in the anions or cations in the medium. They affirmed that the utilization of some compounds in the culture medium resulted in adverse changes in the $\mathrm{pH}$ of the medium. The changes in the $\mathrm{pH}$ of the culture medium produced significant effects on the activities of the enzyme investigated. Kredics et al. (2003) hinted that $\mathrm{pH}$ can also play a role in the regulation of extracellular enzyme production and that Trichoderma strains were active under a wider range of $\mathrm{pH}$ 2.0-7.0. Although $T$. viride (BITRS-1001) grew over a wide range of $\mathrm{pH}$, the optimum PG activity was noticed at $\mathrm{pH} 5.99$ in peptone medium. The $\mathrm{pH}$ of the cultivation is an important factor in the production of pectinases, for it influences the sort and content of those enzymes produced by fungi (Piccoli-Valle et al., 2001).

Changes in $\mathrm{pH}$ of a medium have been reported to affect the affinity of the enzyme for substrates especially when the active site has been altered. A decreased saturation of the enzyme with the substrate as a result of the decrease in affinity may be responsible for the decline in either side of the optimum or may be due to the effect of $\mathrm{pH}$ on the stability of enzymes (Arotupin, 2007). The $\mathrm{pH}$ of the medium in which the enzyme is exposed affects the ionization state of its amino acids which dictate the primary and secondary structure of the enzyme so controlling its activity (Griffin, 1994). The observed reduction in the enzyme activities of Trichoderma viride at $\mathrm{pH}$ values other than the optimal $\mathrm{pH}$ could also be attributed to a probable change in the state of the ionic groups involved in the maintenance of the active conformation of the enzymes. Extreme $\mathrm{pH}$ has been reported to initiate chemical reactions that can alter, cross-link or destroy amino residues of the protein molecules resulting in irreversible inactivation (Arotupin, 2007).

The study has highlighted that the T. viride (BITRS1001) isolate is a good source for producing polygalacturonase on carbon sources other than its natural inducer (pectin) in short incubation period during submerged cultivation. Also, this ability can be further enhanced with the amendment of the culture medium with appropriate nitrogen sources hence a careful manipulation of these nutrient substrates would help optimise the production of this enzymes on a large scale.

\section{REFERENCES}

Adebayo, E. A., Oloke, J. K. and Aina D. A. (2009). Effect of culture parameters of a bacterial consortium on biodegradation of bitumen. American-Eurasian Journal of Sustainable Agriculture 3(1), 46-52.

Adebiyi, F. M., Olise, F. M., Owoade, O. K., Obioh, I. B., Ajayi, T. R., Olaniyi, H. B. and Asubiojo, O. I. (2005). TXRF characterisation of EDTA extractable metals from soils of bituminuous sands occurrence area, Agbabu, South Western Nigeria. Journal of Applied Science 5(7), 1151-1157.

Aiyer, V. P. (2005). Amylases and their applications. African Journal of Biotechnology 4(13), 1525-1529.

Akhilesh, T., Pahwa, R., Singh, S. and Gupta, R. (2010). Production, purification, and characterization of polygalacturonase from Mucor circinelloides ITCC 6025. Enzyme Research. Article ID 170549: 7pp

Akinyosoye, F. A., Adeniran, A. H. and Oboh, G. (2003). Production of fungal amylase from agroindustrial wastes. Peer-Reviewed Proceedings of $16^{\text {th }}$ Annual Conference of Biotechnological Society of Nigeria. pp. 35-40.

Akpan, I. (2004). Screening for novel fungal biocatalysts. Nigerian Journal of Microbiology 18, 288-292. 
Alves, M. H., Campos-Takaki, G. M., Porto, F. A. L. and Milanez, I. A. (2002). Screening of Mucor spp. for the production of amylase, lipase, polygalacturonase and protease. Brazillian Journal of Microbiology 3, 325330.

Arotupin, D. J. (2007). Microbiology and pectinase activity of fungi associated with soils cultivated with different crops. Ph.D Thesis, F. U. T., Akure, Nigeria.

Arotupin, D. J. and Akinyosoye, F. A. (2008). Microbiological and physicochemical characteristics of cassava cultivated soils. Research Journal of Microbiology. 3(1):41-46.

Beg, Q. K., Kapoor, M., Tiwari, R. P. and Hoondal, G. S. (2001). Bleach-boosting of eucalyptus kraft pulp using combination of xylanase and pectinase from Streptomyces sp. QG-11-3. Research Bulletin of the Panjab University 57, 71-78.

Favela-Torres, E., Volke-Sepúlveda, T. and ViniegraGonzález, G. (2006). Production of hydrolytic depolymerising pectinases. Food Technology and Biotechnology 44 (2), 221-227.

Griffin, D. H. (1994). Fungi Physiology. $1^{\text {st }}$ edn. A WileyInterscience, USA. pp. 103-200.

Jacob, N. and Prema, P. (2006). Influence of mode of fermentation on production of polygalacturonase by a novel strain of Streptomyces lydicus. Food Technology and Biotechnology 44(2), 263-267.

Jayani, R. S., Saxena, S. and Gupta, R. (2005). Microbial pectinolytic enzymes: A review. Process Biochemistry 40, 2931-2944.

Kashyap, D. R., Vohra, P. K., Chopra, S. and Tewari, R. (2001). Applications of pectinases in commercial sector: A review. Bioresource Technology 77, 215227.

Khalid, M., Yang, W., Kishwar, N., Rajput, Z. I. and Arijo, A. G. (2006). Study of cellulolytic soil fungi and two nova species and new medium. Journal of Zhejiang University SCIENCE B 7(6), 459-466.

Kredics, L., Antal, Z., Manczinger, L., Szekeres, A. Kevei, F. and Nagy, E. (2003). Influence of environmental parameters on Trichoderma strains with biocontrol potential. Food Technology Biotechnology 41(1), 37-42.

Moore-Landecker, E. (1996). Fundamentals of Fungi. $4^{\text {th }}$ edn. Prentice Hall press, New Jersey, USA. pp. 279310.

Narasimha, G., Sridevi, A., Buddolla, V., Subhosh, C. M. and Rajasekhar, R. B. (2006). Nutrient effects on production of cellulolytic enzymes by Aspergillus niger. African Journal of Biotechnology 5(5), 472-476.

Oboh, B. O, llori, M. O., Akinyemi, O. J. and Adebusoye, S. A. (2006). Hydrocarbon degrading potentials of baceria isolated from a Nigerian bitumen (Tar sand) deposit. Nature and Science 4(3), 51-57.

Oguntimehin, I. I. and Ipinmoroti, K. O. (2007). Solvent extraction of vanadium from Nigerian bitumen using tri-butylphosphate. Journal of Applied Sciences 7(24), 4028-4031.

Onyeocha, I. O. and Ogbonna, C. I. C. (1983). Extracellular enzyme production: A quick qualitative assay method. Nigerian Journal of Biotechnology 1, 48-59.

Palaniyappan, M., Vijayagopal, V., Renuka, V. and Viruthagiri, T. (2009). Screening of natural substrates and optimization of operating variables on the production of pectinase by submerged fermentation using Aspergillus niger MTCC 281 African Journal of Biotechnology 8 (4), 682-686.

Pelczar, M. J., Chan, E. C. S. and Krieg, N. R. (1993). Microbiology. $5^{\text {th }}$ edn. Tata McGrawHill, New Dehli, India. pp. 917.

Piccoli-Valle' R. H., Silva, D. O., Passos, V. J. F. and Passos, L. M. F. (2001). Production of pectin lyase by Penicillium griseoroseum in bioreactors in the absence of inducer. Brazilian Journal of Microbiology, 32(2) doi: 10.1590/S1517-83822001000200013.

Robert, W. B., Elizabeth, M. M. and Ian, T. (2006). Microbiology. Pearson Benjamin Cummings, San Francisco. pp. 758-759.

Silva, R., Lago, E. S., Merheb, C. W., Macchione, M. M., Park, Y. K. and Gomes, E. (2005). Production of xylanase and cmcase on solid substrate fermentation in different residue by Thermoascus aurantiacus Miehe. Brazilian Journal of Microbiology 36, 235-241.

Soares, M. M. C. N., Roberto, S. and Gomez, E. (1999). Screening of bacterial strains for pectinolytic activity: Characterisation of the polygalacturonase produced by Bacillus spp. Revista de Microbiologia 30, 299303.

Vahidi, H., Kobarfard, F. and Namjoyan, F. (2004). Effect of cultivation conditions on growth and antifungal activity of Mycena leptocephala. African Journal of Biotechnology 3(11), 606-609.

Varalakshmi, K. N., Anupama, J., Alva, S., Savia, J., Chiu, Y. Y., Vyshali, P., Shruti, M, Yogeetha, B. S., Bhavya, D., Purvi, J., Ruchi, K., Kumudini, B. S. and Alva, S. (2007). Production and characterization of fungal amylase enzyme isolated from Aspergillus sp. Jg1 12 in solid state culture. African Journal of Biotechnology 6, 576-581.

Vieira, J. D. G., Barbosa, E. C. and Carrim, I. J. A. (2006). Enzymatic activity of endophytic bacterial isolates of Jacaranda decurrens cham. (Carobinhado-campo). Brazillian Archives of Biology and Technology 49(3), 353-359.

Zeki, G., Mustafa, B., Oguzhan, U. and Yunus, S. (2010). Spatial analysis of some physical soil properties in a saline and alkaline grassland soil of Kayseri, Turkey. African Journal of Agricultural Research 5(10), 1127-1137. 